\title{
Potensi Air Tajin Sebagai Pembangkit Listrik Alternatif
}

\author{
Yunitasari $^{1^{*}}$ \\ Program Studi Pendidikan Fisika, FKIP, Universitas Jember \\ Jember 68121, Indonesia \\ e-mail: yunitarahma012@gmail.com
}

Received: 06 Mei 2020. Accepted: 29 Juni 2020. Published: Juli 2020

\begin{abstract}
Abstrak
Air tajin mempunyai banyak kandungan seperti karbohidrat dan elektrolit yang terlarut didalamnya. Kandungan dari air tajin bisa dimanfaatkan sebagai pengganti susu ASI. Hal tersebutlah yang menjadi latar belakang peneliti untuk melakukan suatu inovasi dalam memanfaatkan air tajin sebagai pembangkit listrik alternatif. Tujuan dari penelitian ini untuk mengetahui besar pengaruh frekuensi air tajin sebagai larutan elektrolit dalam menghasilkan sumber energi listrik alternatif serta menentukan massa beras maksimum dalam menghasilkan air tajin sebagai larutan elektrolit. Metode yang digunakan adalah metode penelitian kualitatif untuk mencari tegangan sampel air tajin dengan menentukan massa optimum dan waktu optimum. Variasi massa beras $1 / 2$ liter, beras 1 liter dan adanya penambahan seng, tembaga dengan ukuran $1 \times 5 \mathrm{~cm}, 3 \times 5 \mathrm{~cm}$ dan $5 \times 5 \mathrm{~cm}$. Seperti pada air tajin tambahan seng, tembaga ukuran $1 \times 5 \mathrm{~cm}$ (beras $1 / 2$ liter) diperoleh tegangan sebesar $0.65 \mathrm{~V}, 0.70 \mathrm{~V}, 0.65 \mathrm{~V}, 0.75 \mathrm{~V}$ dan $0.70 \mathrm{~V}$. Sedangkan air tajin (beras 1 liter) diperoleh tegangan sebesar $0.75 \mathrm{~V}, 0.75 \mathrm{~V}, 0.65 \mathrm{~V}, 0.65$ dan 0.70 V.Frekuensi dari penelitian tersebut kurang maksimal apabila dua gelas atau lebih tidak disusun secara seri atau pararel.
\end{abstract}

Kata Kunci: elektroda, air tajin, seng dan tembaga

\section{Potencial of Water Tajin as Alternative Power Plant}

Abstract
Water tajin has many ingredients such as carbohydrates and electrolytes dissolved in it. The content of starch water can be used as a substitute for breast milk. This is the background for researchers to make an innovation in utilizing starch water as an alternative power plant. The purpose of this study was to determine the influence of the frequency of starch water as an electrolyte solution in producing an alternative source of electrical energy and to determine the maximum mass of rice in producing starch water as an electrolyte solution. The method used is a qualitative research method to find the stress of the brine water sample by determining the optimum mass and optimum time. Variations in the mass of rice $1 / 2$ liter, rice 1 liter and the addition of zinc, copper with a size of $1 \times 5 \mathrm{~cm}, 3 \times 5 \mathrm{~cm}$ and $5 \times 5 \mathrm{~cm}$. For example, with added zinc, copper measuring $1 \times 5 \mathrm{~cm}(1 / 2$ liter of rice), the obtained voltage is $0.65 \mathrm{~V}, 0.70 \mathrm{~V}, 0.65 \mathrm{~V}$, $0.75 \mathrm{~V}$ and $0.70 \mathrm{~V}$. While starch water (1 liter of rice) obtained a voltage of $0.75 \mathrm{~V}, 0.75 \mathrm{~V}, 0.65 \mathrm{~V}$, 0.65 and $0.70 \mathrm{~V}$. The frequency of the study was less than optimal if two or more glasses were not arranged in series or parallel.

Keywords: electrode, water tajin, zinc and copper

\section{PENDAHULUAN}

Listrik mempunyai peranan penting dalam proses pembangunan suatu negara, yang mana peran tersebut tidak hanya terbatas sebagai sarana produksi dalam pembangunan sektor prekonomian seperti pertambangan, pendidikan, pertanian, industry dan kesehatan tetapi juga berperan penting dalam memenuhi kebutuhan sosial masyarakat sehari-hari. 


\section{Potensi Air Tajin...Jupiter... Vol 2 No 1...Juli 2020...32-37 Yunitasari}

Walaupun listrik mempunyai peranan penting dalam sektor pembangunan di Indonesia, tetapi pembangunan infrastruktur kelistrikkan di Indonesia masih relatif terbelakang dibandingkan dengan beberapa negara ASEAN. Akibat terlambatnya Negara Indonesia dalam membangun infrastruktur kelistrikan sehingga terjadinya ketimpangan antara hasil produksi dengan konsumsi listrik di Indonesia. Hal tersebut mendorong Indonesia untuk melakukan impor listrik. Impor dilakukan oleh negara Indonesia dengan berlatar belakang bahwa pasokan listrik dalam negeri masih kurang dan masih banyak pembangkit listrik mahal dengan berbahan BBM. Sedangkan konsumsi listrik di Indonesia dari tahun ke tahun mengalami peningkatan, kenaikan komsumsi listrik banyak didominasi rumah tangga.

Semakin banyak kebutuhuan listrik di lingkungan rumah tangga melatar belakangi peneliti untuk memanfaatkan air tajin sebagai pembangkit listrik alternatif. Air tajin atau sering disebut sebagai air beras merupakan air yang diperoleh pada saat setelah mencuci beras, kemudian di didihkan dan ditambah garam sekitar 1/2sendok makan untuk setiap liter air. Karbohidrat yang terlarut pada air tajin, mengandung elektrolit dan $\mathrm{pH}$ larutan yang dianggap aman, efesien dapat digunakan untuk rehidrasi (Rahmanika dan Oktaria, 2018: 615).

Air leri (bahasa Jawa) atau sering dikenal dengan sebutan air cucian beras yang mempunyai warna putih susu, warna tersebut menunjukkan bahwa kandungan vitamin B1 dan protein pada beras juga akan ikut terkikis pada saat proses pencucian beras (Supraptiningsih, et al, 2019). Selain itu,air cucian beras juga dikenal banyak mempunyai kandungan beberapa unsur seperti, posfor, dan juga nutrisi, antara lain $70 \%$ vitamin B3, 90\% vitamin B6, 50\% fosfor
(P), 80\% Vitamin B1, 100\% serat, 60\% zat besi (Fe), $50 \%$ mangan (Mn) dan asama lemak esensial (Suwardani, dkk, 2019: 45).

Energi listrik yang terjadi pada reaksi elektrokimia bisa terjadi dengan melalui dua jenis elektroda yang mempunyai beda potensial dan dapat terhubung dengan bahan elektrolit (Mukminin, et al, 2018: 92). Menurut Chang (2003), menjelaskan bahwa pada semua zat yang dapat terlarut didalam air dibagi menjadi 2 kelompok yang terdiri dari zat elektrolit dan zat non elektrolit. Zat elektrolit merupakan zat yang apabila dilarutkan dengan air, akan dihasilkan larutan yang bisa menghasilkan tegangan arus listrik. Larutan elektrolit dibedakan menjadi 2 macam, yaitu elektrolit kuat dan lemah. Sedangkan zat non elektrolik merupakan zat yang apabila dilarutkan dengan air, tidak bisa menghasilkan tegangan arus listrik (Satrio, 2016: 92). Menurut Unila (2013), menjelaskan bahwa larutan elektrolit dapat diartikan sebagai larutan yang diperoleh pada proses pencampuran 2 zat atau lebih yang apabila dicampur secara homogen salah satu dari 2 zat tersebut bertindak sebagai zat terlarut dan lainnya sebagai zat pelarut (Bengi, dkk, 2018:32).

Menurut Underwood (1999) dalam Siti, dikatakan bahwa elektrolit merupakan suatu senyawa yang dapat berikatan ion ataupun kovalen polar. Misalnya seperti ikatan ion yang terjadi pada $\mathrm{NaCl}$. $\mathrm{NaCl}$ (Natrium Clorida) adalah jenis garam, yang sering dikenal sebagai garam dapur. $\mathrm{NaCl}$ bisa berubah menjadi elektrolit apabila dalam bentuk larutan atau lelehan. Akan tetapi apabila $\mathrm{NaCl}$ dalam bentuk padatan, maka senyawa ion yang terkandung pada $\mathrm{NaCl}$ tidak bisa mempunyai fungsi sebagai elektrolit (Zikriana dan Hamid, 2017: 460).

Berdasarkan percobaan yang telah dilakukan oleh Setiawan, et al 
(2020:202-205) dengan menggunakan dua macam air dalam mencuci beras (air pam dan air sumur), selain itu menggunakan ukuran seng dan tembaga yang bervariasi $(1 \times 5 \mathrm{~cm}, 2 \times 5 \mathrm{~cm}$ dan $3 \times 5 \mathrm{~cm}$ ). Pada air pam (beras 1,5 liter) dengan menggunakan ukuran tembaga dan seng sebesar $1 \times 5 \mathrm{~cm}$ diperoleh tegangan rata-rata sebesar $0,59 \mathrm{~V}$. Sedangkan pada air sumur (beras 3 liter) dengan menggunakan ukuran seng dan tembaga sebesar $1 \times 5 \mathrm{~cm}$ diperoleh tegangan rata-rata sebesar $0,62 \mathrm{~V}$. Pada percobaan kedua dengan menggunakan ukuran tembaga dan seng sebesar $2 \times 5$ $\mathrm{cm}$, pada air pam (beras 1,5 liter) diperoleh tegangan rata-rata sebesar 0,66 V. Sedangkan pada air sumur (beras 3 liter) diperoleh tegangan rata-rata sebesar $0,58 \mathrm{~V}$. Jadi tegangan yang diperoleh dari percobaan tersebut kurang maksimal dikarenakan dua gelas atau lebih yang tidak dijadikan dalam rangkaian pararel/ seri, sehingga hasil yang diperoleh tidak maksimal.

Permasalahan yang akan ditinjau dalam penelitian ini adalah: Bagaimana besar pengaruh frekuensi air tajin sebagai larutan elektrolit dalam menghasilkan sumber energi listrik alternatif, serta besar massa beras maksimum dalam menghasilkan air tajin sebagai larutan elektrolit.

Tujuan dari penelitian ini untuk mengetahui besar pengaruh frekuensi air tajin sebagai larutan elektrolit dalam menghasilkan sumber energi listrik alternatif, serta untuk mengetahui massa beras maksimum dalam menghasilkan air tajin sebagai larutan elektrolit.

\section{BAHAN DAN METODE}

Metode yang digunakan dalam penelitian ini adalah metode penelitian kualitatif dengan menerapkan sistem elektroda pada sampel air tajin yang diperoleh dari proses perubusan beras yang kemudian diambil airnya untuk mengetahui besar tegangan yang dihasilkan dan menentukan massa optimum beras dalam memperoleh air tajin sebagai larutan elektrolit. Penelitian akan dilaksanakan di Mojokerto, Jawa Timur pada tanggal 18 April 2021. Dalam penelitian ini yang dibuat bervariasi adalah ukuran seng dan ukuran tembaga.

Variabel yang terdapat dalam penelitian tersebut, yaitu,variabel terkontrol: volume air,massa garam, jumlah sampel (5), varibel terikat: tegangan, variabel bebas: waktu interaksi (fermentasi selama 12 jam), massa beras.

\section{Alat dan Bahan \\ Alat}

1. Multimeter digital

2. Seng, ukuran $1 \times 5 \mathrm{~cm}$ (sejumlah 5 buah), $3 \times 5 \mathrm{~cm}$ (sejumlah 5 buah), $5 \times 5 \mathrm{~cm}$ (sejumlah 5 buah).

3. Tembaga (ketebalan 0,2 $\mathrm{mm}$ ), ukuran $1 \times 5 \mathrm{~cm}$ (sejumlah 5 buah), ukuran $3 \times 5 \mathrm{~cm}$ (sejumlah 5 buah), ukuran $5 \times 5 \mathrm{~cm}$ (sejumlah 5 buah).

4. Gelas plastic

5. Baskom untuk menampung air tajin

6. Panci dan pengaduk nasi

7. Saringan

8. Sendok

9. Penggaris

10. Gunting/ silet

\section{Bahan}

1. Beras $1 / 2$ liter dan 1 liter

2. Air 1,5 liter (2 botol)

3. Garam 1 gram 
Potensi Air Tajin...Jupiter... Vol 2 No 1...Juli 2020...32-37 Yunitasari

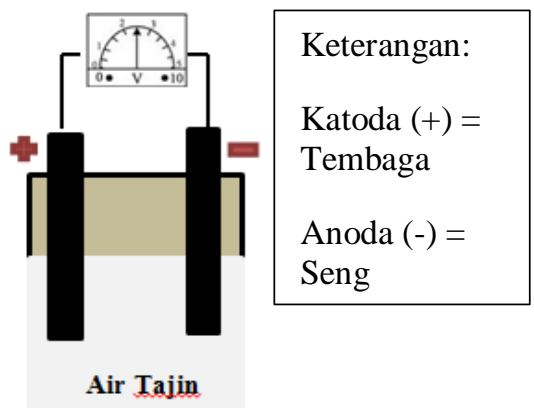

Gambar 1. Rangkaian Elektroda

\section{HASIL DAN PEMBAHASAN}

Hasil yang diperoleh dari penelitian menujukkan bahwa besar nilai tegangan yang dihasilkan dari 5 sampel dengan menggunakan massa beras, ukuran tembaga dan seng yang berbeda. Hasil pengukuran baru bisa dilakukan setelah 12 jam air tajin didiamkan. Hasil penilitian tersebut dapat dilihat pada Tabel 1.

Tabel 1. Besar Tegangan Pada Larutan Air Tajin

\begin{tabular}{ccc}
\hline $\begin{array}{c}\text { Jenis Ukuran } \\
\text { Tembaga dan Seng }\end{array}$ & $\begin{array}{c}\text { Air tajin } \\
\text { (beras 1/2 liter) }\end{array}$ & $\begin{array}{c}\text { Air tajin } \\
\text { (beras 1 liter) }\end{array}$ \\
\hline \multirow{3}{*}{$1 \times 5 \mathrm{~cm}$} & $0,65 \mathrm{~V}$ & $0,75 \mathrm{~V}$ \\
& $0,70 \mathrm{~V}$ & $0,75 \mathrm{~V}$ \\
& $0,65 \mathrm{~V}$ & $0,65 \mathrm{~V}$ \\
$0,75 \mathrm{~V}$ & $0,65 \mathrm{~V}$ \\
$0,70 \mathrm{~V}$ & $0,70 \mathrm{~V}$ \\
$0,70 \mathrm{~V}$ & $0,70 \mathrm{~V}$ \\
$3 \times 5 \mathrm{~cm}$ & $0,75 \mathrm{~V}$ & $0,65 \mathrm{~V}$ \\
& $0,70 \mathrm{~V}$ & $0,75 \mathrm{~V}$ \\
& $0,65 \mathrm{~V}$ & $0,70 \mathrm{~V}$ \\
& $0,70 \mathrm{~V}$ & $0,75 \mathrm{~V}$ \\
& $0,75 \mathrm{~V}$ & $0,75 \mathrm{~V}$ \\
$5 \times 5 \mathrm{~cm}$ & $0,70 \mathrm{~V}$ & $0,70 \mathrm{~V}$ \\
& $0,70 \mathrm{~V}$ & $0,65 \mathrm{~V}$ \\
& $0,75 \mathrm{~V}$ & $0,75 \mathrm{~V}$ \\
& $0,65 \mathrm{~V}$ & $0,75 \mathrm{~V}$ \\
\hline
\end{tabular}

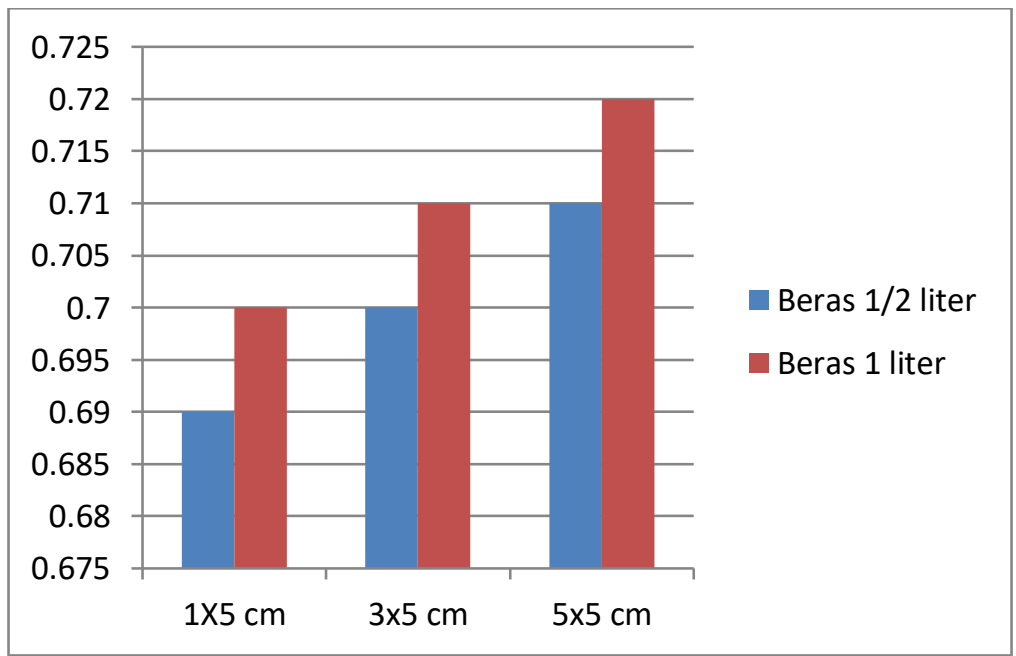


Gambar 2. Grafik Perbandingan rata-rata tegangan dari massa beras, ukuran tembaga dan seng yang berbeda.

Berdasarkan data hasil penelitian pada Tabel 1 dapat diketahui bahwa, pada saat menggunakan tembaga dan seng ukuran $1 \times 5 \mathrm{~cm}$ hasil pengukuran tegangan air tajin (beras $1 / 2$ liter) secara berurutan $0.65 \mathrm{~V}, 0.70 \mathrm{~V}, 0.65 \mathrm{~V}, 0.75$ $\mathrm{V}$ dan 0.70 V. Sedangkan hasil tegangan pada air tajin (beras 1 liter) secara berurutan $0.75 \mathrm{~V}, 0.75 \mathrm{~V}, 0.65$ $\mathrm{V}, 0.65 \mathrm{~V}$ dan $0.70 \mathrm{~V}$. Hasil tersebut menunjukkan bahwa terdapat dengan bertambahnya massa beras, maka besar tegangan yang dihasilkan juga akan semakin besar walaupun itu kecil.

Berdasarkan hasil percobaan dapat diketahui bahwa, pada saat menggunakan tembaga dan seng ukuran $3 \times 5 \mathrm{~cm}$ hasil pengukuran tegangan air tajin (beras $1 / 2$ liter) secara berurutan $0.70 \mathrm{~V}, 0.75 \mathrm{~V}, 0.70 \mathrm{~V}, 0.65 \mathrm{~V}$ dan 0.70 V. Sedangkan hasil tegangan pada air tajin (beras 1 liter) secara berurutan $0.70 \mathrm{~V}, 0.65 \mathrm{~V}, 0.75 \mathrm{~V}, 0.70 \mathrm{~V}$ dan 0.75. Hasil tersebut menujukkan bahwa dengan bertambahnya massa dan tambahan seng, tembaga dengan ukuran $3 \times 5 \mathrm{~cm}$, maka tegangan yang diperoleh akan lebih besar dibandingkan dengan menggunakan tambahan seng, tembaga ukuran 1x5 cm. Menurut Yayu (2011), Air tajin mengandung 80\% vitamin $\mathrm{B} 1,50 \% \mathrm{Mn}$, serat $100 \%$, $70 \%$ vitamin B3,50\% fosfor, $60 \%$ Besi (Lestari dan Rahman, 2019: 126).

Berdasarkan hasil percobaan dapat diketahui bahwa, pada saat menggunakan tembaga dan seng ukuran $5 \times 5 \mathrm{~cm}$ hasil pengukuran tegangan air tajin (beras $1 / 2$ liter) secara berurutan $0.75 \mathrm{~V}, 0.70 \mathrm{~V}, 0.70 \mathrm{~V}, 0.75 \mathrm{~V}$ dan 0.65 $\mathrm{V}$. Sedangkan hasil tegangan pada air tajin (beras 1 liter) secara berurutan $0.75 \mathrm{~V}, 0.70 \mathrm{~V}, 0.65 \mathrm{~V}, 0.75 \mathrm{~V}$ dan 0.75 $\mathrm{V}$. Hasil tersebut menunjukkan bahwa dengan bertambahnya massa dan tambahan seng, tembaga dengan ukuran $5 \times 5 \mathrm{~cm}$, maka tegangan yang diperoleh akan lebih besar dibandingkan dengan menggunakan tambahan seng, tembaga ukuran $3 \times 5 \mathrm{~cm}$. Energi listrik yang terjadi pada reaksi elektrokimia bisa terjadi dengan melalui dua jenis elektroda yang mempunyai beda potensial dan dapat terhubung dengan bahan elektrolit (Mukminin, et al, 2018:92).

\section{KESIMPULAN}

Berdasarkan pembahasan diatas dapat diambil kesimpulan sebagai berikut:

1. Air tajin atau sering disebut sebagai air beras merupakan air yang diperoleh pada saat setelah mencuci beras, kemudian di didihkan dan ditambah garam sekitar 1 gram untuk setiap 1,5 liter air. Karbohidrat yang terlarut pada air tajin, mengandung elektrolit. Berdasarkan percobaan sedehana yang telah dilakukan didapatkan tiga nilai tegangan yang berbeda pada perbedaan ukuran seng, temabga dengan ukuran $1 \times 5 \mathrm{~cm}$, $3 \times 5 \mathrm{~cm}$ dan $5 \times 5 \mathrm{~cm}$ mengalami peningkatan dengan semakin besar ukuran seng, tembaga dan massa beras. Seperti pada Grafik 1 pada air tajin (beras $1 / 2$ liter) secara berurutan $0.69 \mathrm{~V}, 0.7 \mathrm{~V}$ dan $0.71 \mathrm{~V}$. Sedangkan pada air tajin (beras 1 liter) secara berurutan $0.7 \mathrm{~V}, 0.71 \mathrm{~V}$ dan $0.72 \mathrm{~V}$.

2. Air tajin bisa dimanfaatkan sebagai salah satu pembangkit listrik alternatif, walaupun tegangan yang dihasilkan sangat kecil, agar tegangan yang dihasilkan lebih besar dan maksimal sebaiknya 
dilakukan pengembangan sistem rangkaian seri dan pararel pada dua gelas atau lebih.

\section{DAFTAR PUSTAKA}

Bengi, Fitri Mah., Wahyuni, Ayu Sri., Syamsuryani, Wahyu dan Mustika Dona. 2018. Perbandingan Arus Dan Tegangan Larutan Elektrolit Berbagai Jenis Garam. Jurnal Pendidikan Fisika dan Sains 1(1): 32-36.

https://ejurnalunsam.id/index.php/ JPFS/article/view/1724/1325

Lestari, Pertiwi Indah dan Rahman. 2019. Pengaruh Liquid State Fermentatition Terhadap Pertumbuhan Tanaman Tomat. Jurnal Ekosistem 19(2): 125-139. https://ecosystem.universitasboso wa.ac.id/index.php/eco/article/vie $\underline{w} / 165$

Mukminin, Giri Amirul., Pauzi, Gurum Ahmad dan Warsito. 2018. Analisis Potensi Elektrik Berbagai Elektrolit Alam Sebagai Sumber Energi Terbarukan. Jurnal Teori dan Aplikasi Fisika 6(1): 91-100. https://jurnal.fmipa.unila.ac.id/jtaf /article/view/1830

Rahmatika, Achisna dan Oktaria, Dwita. 2018. Penggunaan Air Tajin (Air Beras) untuk Rehidrasi Oral pada Penatalaksanaan Deman Dengue. Jurnal Agromedicine Unila 5(2): 611616.

https://juke.kedokteran,unila.ac.id /index.php/agro/article/view/2121

Satrio, Benny Yanuar Dwi. 2016. Modul Kimia Berbasis EPUB untuk Siswa Tunanetra.Jurnal StudiDisabilitas $\quad 3(1)$ : $\quad 87$ - 108.https://ejournal.uin.suka.ac.id /pusat/inklusi/article/view/1906

Setiawan, Didik., Aji, Mahardika Prasetya dan Astuti, Budi. 2020. Pembuatan Elektroda Berbahan Air Cucian Beras. Prosiding Seminar Nasional Pascasarjana. Semarang: Pascasarjana Pendidikan Fisika Universitas Negeri Semarang.

Supraptiningsih, Linda Kurnia., Nuriyati, Rofikha dan Sutrisno, Adi. 2019. Pengelolaaan Limbah Rumah Tangga (Air Leri) Menjadi Pupuk Organik Cair (POCA) di Kabupaten Probolinggo. Jurnal Pengabdian Masyarakat Fakultas Psikologi UM Jember 3:12-20. https://jurnal.unmuhjember.ac.id/i ndex.php/EMPOERING/article/vi ew/SUP

Suwardani, Yuli., Ansoruddin dan Purba, Deddy Wahyudin. 2019. Pengaruh Teknik Pemberian Air Cucian Beras dan Waktu Penyemprotan Air Terhadap Pertumbuhan dan Produksi Tanaman Tomat (Solanum lycopersicum L). Jurnal Penelitian Pertanian 15(3): 44-53. https://jurnal.una.ac.id/index.php/j b/article/view/1220/0

Zikriana, Lissa dan Hamid, Abdul. 2017. Perbandingan Tegangan yang Diberi Larutan Garam dengan Massa yang Berbeda untuk Menggerakkan Kipas Angin Sederhana. Prosiding Seminar Nasional MIPA III. Aceh: Program Studi Fisika FKIP Universitas Syiah Kuala Banda Aceh. 